\title{
A Note on Utrecht Allegory
}

\section{W.H. New}

\section{(2) OpenEdition}

1 Journals

Electronic version

URL: https://journals.openedition.org/ces/4998

DOI: 10.4000/ces.4998

ISSN: 2534-6695

\section{Publisher}

SEPC (Société d'études des pays du Commonwealth)

\section{Printed version}

Date of publication: 1 April 2015

Number of pages: 11-14

ISSN: 2270-0633

\section{Electronic reference}

W.H. New, "A Note on Utrecht Allegory", Commonwealth Essays and Studies [Online], 37.2 | 2015, Online since 13 April 2021, connection on 18 July 2021. URL: http://journals.openedition.org/ces/4998 ; DOI: https://doi.org/10.4000/ces.4998

\section{(c) (i) (5)}

Commonwealth Essays and Studies is licensed under a Licence Creative Commons Attribution - Pas d'Utilisation Commerciale - Pas de Modification 4.0 International. 


\section{A Note on Utrecht Allegory}

Alice Munro's “The Peace of Utrecht” first appeared in Tamarack Review in 1960, ${ }^{1}$ eight years before it was collected as the penultimate story in Dance of the Happy Shades. Often cited as one of the strongest stories in this first collection, the story is generally read as a feminist study of sisterhood and a covert portrait of Munro's mother. ${ }^{2}$ Few critics fasten for long on the implications of the title. ${ }^{3}$ This note comments briefly on ways in which the titular allusion to the Peace of Utrecht constitutes a substantial and even allegorical function in the story rather than functioning simply as a metaphor for the sisters' momentary entente.

I use the term "allegory" cautiously, for I do not wish to imply any mechanical correspondence between the terms of the historical Peace of Utrecht (involving France, Spain, England, Holland, Portugal, and the Kingdom of Savoy) and the events that the story records: Helen's return visit to Jubilee, from her life and family on the Coast; her awkward relation with her sister Maddy, who has stayed at home to look after their ailing mother; contemporary events in the town; memories of their mother's behaviour as her Parkinsonism and dementia progressed; a funeral; a broken bowl; and a moment of connection (and disconnection) between the sisters that questions the possibility and indeterminacy of identity. Even Munro's earliest stories do not rely on automatic equivalences, and Helen, Maddy, and their mother do not somehow represent England, France, and Spain or any other combination of competing nations. I am, however, suggesting that the historical Treaty of Utrecht does resonate through the story like an arching analogy or cambered metaphor, one that contextualizes the sisters' conflict and informs their fragile peace.

Aside from the title, only one mention of "The Peace of Utrecht, 1713" appears in Munro's story. It occurs when Helen, the narrator, mentions staying in a "strange" room with her children (a room that for them was "safe" - merely "another strange place to go to sleep," a different order of defamiliarization from that which dislocated Helen herself). Opening a washstand drawer, she discovers a page from her own high school history notes, reading: "The Peace of Utrecht, 1713, brought an end to the War of the Spanish Succession' [...] it looked as if I might have written it that day [...] I felt as if my old life was lying around me, waiting to be picked up again" (201). It is not just her adolescence she fears revisiting (details of which are mentioned elsewhere in the story: embarrassment, behaviour, schooling) but also the set of values that is epitomized by a twentieth-century Ontario schoolbook's preoccupation with eighteenth and nineteenth-century Imperial history. In other words, the single mention is not a casual aside in the story - details in an Alice Munro story are always more than casual - but a

1. Tamarack Review 15 (Spring 1960): 5-21.

2. See, e.g., Isla Duncan18-25; Ailsa Cox 21-2; Magdalene Redekop 50-7; and Robert Thacker 149-54.

3. The most thorough is E. D. Blodgett, who emphasizes that the peace is not lasting, however much the illusion of peace is desired. The homonyms peace and piece suggest the stylistic overlap between resolution and dissolution. See also Ajay Heble (41-2), and Coral Ann Howells (19-22), who cite "war" as an important element in the story, Heble stressing it as a central subject (peace being only a way of making the past agreeable), and Howells emphasizing that the narrative focus falls on domestic matters. Redekop also suggests that the illusion of control is a way of denying chaos (150). 
way of helping to elucidate how a set of social values impinges on personal choice and private action.

The details of the Treaty of Utrecht in 1713 are complex and not uniformly relevant to list here. More important is the fact that the Peace actually refers to a series of treaties, signed over several years, which were changing both the map of Europe and European control in the Americas. They were also, in more diffuse ways, negotiating shifting determinations of power. Among the most salient features of the Peace are the following:

1. The Treaty signifies the end of the War of the Spanish Succession, by which Louis XIV's grandson Philip acquired the Spanish throne, but his other grandsons gave up any claim to it, and Philip's progeny gave up all claims to the French throne;

2. Spanish possessions were partially redistributed, in Europe and the Americas (Gibraltar to Britain, Sicily to Savoy, Amazon lands to Portugal, and the Spanish Netherlands and other territory to Charles VI, Holy Roman Emperor and Archduke of Austria);

3. Spanish control over the African slave trade was ceded to Britain;

4. France ceded to Britain its claims to Newfoundland, Acadia, St. Kitts, and the Hudson's Bay territories (Rupert's Land), though kept other North American territories, including Quebec.

5. France recognized the right of the Protestant House of Hanover to succeed Queen Anne (of the House of Orange) to the throne of Great Britain, thus reconfirming the authority of Queen Anne's Act of Succession (1701) and surrendering French support of the Catholic pretenders to the British throne (who were then resident in France).

Early national English-language Canadian history textbooks emphasized the clauses involving land claims in northern North America, rather than changes in the royal houses of Europe. That these land claims were so specifically based on blatantly predatory commercial advantages (the fur trade, the sugar trade, the fish trade, the slave trade) was also less readily acknowledged. But they serve as a powerful context for Munro's story and for the Ontario community the story portrays. ${ }^{4}$

More important than the specifics of the Treaty of Utrecht negotiations, for reading Alice Munro's story, are the ramifications of the systems and hierarchies of power that shaped the agreements: i.e., church, state, territory, and gender, all of which continue to structure life in the sisters' town of Jubilee. The invented place name Jubilee, for instance, implicitly speaks of Empire - the Diamond Jubilee of Queen Victoria (of the House of Hanover/Saxe-Cobourg-Gotha) having been celebrated throughout settled

4. Despite the 1713 Treaty, France and Spain remained at war with the Holy Roman Emperor, and Spain and Portugal continued to be formally at war with each other, until more treaties were signed. Moreover, the balance of power amongst the signatories would be repeatedly upset as further conflicts resumed over the next 250 years. The Seven Years' War between England and France renewed hostilities, coming to a conclusion in 1763, with francophone Canada ceded to Britain, for example. Thirteen American colonies rebelled against Britain in 1776, forming the United States of America. And Ireland became a centuries-long site of religious and social conflict after having been occupied by Protestant British forces during the seventeenth century reign of Anne's brother-in-law, King William III. The famines of the midnineteenth century, the result of people being forced off the land, led to widespread Irish emigration to North America, largely Protestant in Ontario by 1814, when Irish emigrants moved north during and after the American Revolution, and largely Catholic after 1840, many to rural Western Ontario. Protestant-Catholic tensions increased in Ontario during the Fenian raids across the American border in the late 1860s. Southwestern Ontario towns were characteristically divided by sectarian adherence, as is represented in the judgmental attitudes of the older generation in Jubilee. 
Canada in 1897..$^{5}$ Doctrinal differences between predestination and free will govern certain strands of social behaviour and certain interpretations of gendered role. The difference between the sisters' mother and aunts is in some measure replicated in the difference between Helen and Maddy. Their mother is a rule-breaker, acting as though outside social conventions - and is therefore considered embarrassing. Their aunts Annie and $\mathrm{Lou}^{6}$ are by contrast devoted to Protestant duty and the solemn rituals of thrift and work. They make rag rugs; they would recycle old clothes; their house "is very clean, dark and varnished, and it smells of vinegar and apples" (203). The question is: who acts, and who cannot act? Or who blames, and who suffers blame? Or who chooses, and who cannot bring herself to choose? Helen acts, to a degree, because Maddy has given her the opportunity for an education, which Helen then gives up for marriage and family and distance. Maddy would act, but resents that she feels she cannot, because accepting family responsibility has denied her the opportunities that she offered to her sister. Helen's absent husband and Maddy's "amiable," "affable" friend Fred occupy the "peaceable" (193) background, but neither is an active agent of change. Nor is either sister free from Jubilee, whether in it or away. Duty and responsibility enmesh them in a system of values, and paradox dooms them to stalemate.

"Allegory" in the story, therefore, does not re-enact the treaty-making process that led to the 1713 Peace of Utrecht so much as it sets in motion a mode of understanding, an acceptance of an order of life, with which the sisters must negotiate. "Treaty-making" in the story takes place not solely in the talk that leads to the stiff peace between the sisters, but also in every other narrative relationship: between Maddy and Fred, between the sisters and their mother, between Helen and the Aunts, and most obviously among the players at the town party (from which Helen tries to exclude herself): "During the game [...] all the women put an article of clothing - it begins decorously with a shoe - in a basket, and then all the men come in and have a race trying to fit things on to their proper owners" (192). The adjective "proper" bristles with meaning: having to do with agreed-upon reality, with orthodoxy or convention, with property. The game turns the women into territory, each woman susceptible to trade. The 1713 Treaty had dealt in port advantages (Gibraltar, Sicily), product sources (Newfoundland, St. Kitts, Rupert's Land, for fish, sugar, fur; and Africa, for slaves, treated as chattel, or property, in imperial trade law). Munro's "The Peace of Utrecht" acknowledges the Imperial and commercial shape of the town of Jubilee (the Queen's Hotel and the service station on the main street, the bottling-plant and the Tastee-Freez on the north side, 196). More devastating is the portrait of the sisters as slaves to a commodified world and the inherited systems of value they cannot shed.

Formally, Munro sets up this contention in the first paragraph of "The Peace of Utrecht," when Helen as narrator begins in what sounds like the present to recount her

5. County and district name changes in Upper Canada (later Ontario) reiterate this Imperial history. In 1788, southern Ontario - territory that had still been considered part of the Province of Quebec - was subdivided into districts named Hesse, Lunenburg, Mecklenburg, and Nassau (after House of Orange-Nassau). In Southwestern Ontario, these German and Dutch names gave way to such English county names as Essex, Middlesex, Kent, and Oxford in 1798. The rural Huron District, the site of the fictional Jubilee, was formed in 1838.

6. These "royal" names - after Queen Anne and Princess Louise, but reshaped as demotic nicknames here - were in common use through the eighteenth and nineteenth centuries. Helen's daughter's name, Margaret, continues the royal naming practice (many twentieth-century girls were named for Princess Margaret Rose). By contrast, the names Maddy (i.e., Madeleine $=$ maiden $)$ and Helen $($ Greek=bright torch $)$ suggest political resonances related to European tale and gendered social roles. 
visit to Maddy and their likely failure to sort out their differences permanently: "I have been at home now for three weeks and it has not been a success" (190). The story goes on to use simple present forms of the verb, which maintain the illusion of a narrative unfolding as it is being read. But the opening paragraph uses the present perfect form: have been, indicating action already completed. Helen's words drift into a future declared necessary ("we will have to look straight into the desert" [190, emphasis added]) before announcing rejection and drifting back into the fixed and unshared past: "each of us [...] thinking [...] that the other has turned alien, and forfeited her claim" (190, emphasis added). In other words, in the narrative yet to unfold, time also becomes territory. The story turns on the shifting ground of ownership over action and event, which justifies (at least for each claimant) agreements reached and choices made. Behind these choices lies the allegory of inheritance that the reader gradually learns to appreciate the realization that the competitive terms of power-exchange reverberate across time, and that an apparent freedom of choice does not automatically mean freedom from rule. Resisting closure (as is characteristic of Munro's fiction), "The Peace of Utrecht" nevertheless offers a rare comment on settlement (in both its meanings) and the social politics that brings it about.

W.H. NEW

University of British Columbia

\section{Works Cited}

Blodgett E. D. Alice Munro. Boston: Twayne, 1988.

Cox, Ailsa. Alice Munro. Horndon: Northcote House, 2004.

Duncan, Isla. Alice Munro's Narrative Art. New York: Palgrave-Macmillan, 2011.

Heble, Ajay. The Tumble of Reason. Toronto: U Toronto P, 1994.

Howelds, Coral Ann. Alice Munro. Manchester: Manchester UP, 1998.

Munro, Alice. Dance of the Happy Shades. Toronto: McGraw-Hill Ryerson, 1968.

Redekop, Magdalene. Mothers and Other Clowns. London \& New York: Routledge, 1992.

Thacker, Robert. Alice Munro. Toronto: McClelland \& Stewart, 2001. 